\title{
PERBEDAAN PRESTASI BELAJAR AKUNTANSI DENGAN MENGGUNAKAN METODE PEMBELAJARAN KOOPERATIF TIPE SNOWBALL THROWING DAN TALKING STICK PADA SISWA KELAS XII IPS DI SMA NEGERI 1 WUNGU
}

\author{
Ratnajuwita Danar Sari, Satrijo Budi Wibowo dan Juli Murwani \\ Program Studi Pendidikan Akuntansi - FPIPS \\ IKIP PGRI MADIUN
}

\begin{abstract}
ABSTRAK
Pembelajaran merupakan suatu proses dalam rangka menciptakan suasana yang memungkinkan siswa dapat belajar dengan nyaman. Dalam proses pelaksanaan pembelajaran terdapat berbagai cara atau keterampilan yang digunakan untuk menciptakan kondisi siswa dalam belajar. Penelitian ini bertujuan untuk mengetahui: Apakah terdapat perbedaan prestasi belajar akuntansi siswa kelas XII IPS SMA Negeri 1 Wungu dengan metode pembelajaran kooperatif tipe Snowball Throwing dengan Talking Stick. Penelitian ini menggunakan desain penelitian hubungan komparatif. Objek dalam penelitian ini adalah siswa di SMA Negeri 1 Wungu. Populasi penelitian adalah seluruh siswa kelas XII IPS SMA Negeri 1 Wungu sejumlah 32 siswa. Penentuan sampel dengan teknik sampling jenuh yaitu penentuan sampelnya sejumlah populasi yaitu 32, 16 siswa kelas XII IPS 1 sebagai kelas Snowball Throwing dan 16 siswa kelas XII IPS 2 sebagai kelas Talking Stick. Teknik pengumpulan data yang digunakan adalah teknik tes. Data diperoleh dari soal tes yang telah dilakukan uji validitas dan reliabilitas. Teknik analisis data menggunakan analisis variansi satu jalan sel sama dengan taraf signifikansi 0,05. Kesimpulan dari penelitian ini menunjukkan bahwa: Ada perbedaan prestasi belajar akuntansi siswa kelas XII IPS SMA Negeri 1 Wungu dengan menggunakan metode pembelajaran kooperatif tipe Snowball Throwing dengan tipe Talking Stick. Penggunaan metode pembelajaran kooperatif tipe Snowball Throwing lebih sesuai dari pada metode pembelajaran kooperatif tipe Talking Stick dalam peningkatan prestasi belajar akuntansi siswa kelas XII IPS SMA Negeri 1 Wungu, karena ada peningkatan keaktifan belajar siswa dari segi kerjasama, bertanya dan menjawab pertanyaan dengan model pembelajaran baik dengan teknik tanya jawab berpasangan maupun dengan diskusi kelompok.
\end{abstract}

Kata Kunci : Pembelajaran Kooperatif, Metode Pembelajaran tipe Snowball Throwing, Metode Pembelajaran tipe Talking Stick, dan Prestasi Belajar Akuntansi.

\section{PENDAHULUAN}

Pembelajaran merupakan suatu proses dalam rangka menciptakan suasana yang memungkinkan siswa dapat belajar dengan nyaman. Dalam proses pelaksanaan pembelajaran terdapat berbagai cara atau ketrampilan yang digunakan untuk menciptakan kondisi siswa dalam belajar. Oleh karena itu pembelajaran tidak terlepas dari peran guru sebagai orang yang berperan untuk menyalurkan pengetahuannya serta ketrampilannya, selain itu juga memandu segenap proses pembelajaran. Proses pembelajaran yang dijalankan harus memiliki tujuan, tujuan tersebut yaitu untuk membekali siswa ilmu pengetahuan dan pengalaman. Selain itu pembelajaran harus memiliki aspek dinamis yang sangat penting yaitu motivasi. Sering terjadi siswa yang kurang berprestasi bukan disebabkan oleh kemampuannya yang kurang, tetapi dikarenakan kurang adanya motivasi untuk belajar sehingga siswa tidak berusaha untuk mengarahkan segala kemampuannya. 
Akuntansi merupakan salah satu bidang studi yang mempunyai peranan penting dalam dunia pendidikan dan dunia bisnis. Pelajaran akuntansi dalam pelaksanaan pendidikan diberikan pada jenjang pendidikan sekolah menengah atas sampai perguruan tinggi, akan tetapi pelajaran akuntansi diberikan secara kompleks pada sekolah kejuruan dan lebih diutamakan dalam hal praktiknya.

Kebanyakan di SMA/SMK proses pembelajarannya cenderung text book oriented dan teacher centered yaitu siswa membuka buku, mendengarkan guru menjelaskan materi, mencatat dan mengerjakan latihan. Sehingga siswa menjadi kurang aktif dalam proses pembelajaran. Seharusnya dalam proses pembelajaran sehari-hari dipusatkan pada siswa (student centered) agar siswa menjadi pribadi yang kritis dan mandiri. Pada mata pelajaran akuntansi, guru memegang peranan penting dalam mewujudkan tercapainya tujuan pembelajaran. Selain menjelaskan konsep dan prinsip, seorang guru akuntansi juga dituntut untuk menciptakan kondisi kelas yang baik agar siswa terlibat secara aktif dalam proses pembelajaran.

Menurut hasil wawancara peneliti dengan guru akuntansi, di dalam kegiatan pembelajaran terjadi proses yang harus dilewati oleh seorang siswa di mana proses pembelajaran ini menjadi penentu untuk mencapai tujuan dari pembelajaran itu sendiri. Salah satu faktor yang menyebabkan kurangnya perhatian siswa terhadap kegiatan belajar mengajar diantaranya disebabkan oleh kurang bervariasinya penggunaaan metode pembelajaran dalam kegiatan belajar. Menurut keterangan yang diperoleh dari hasil wawancara dengan siswa, bahwa mayoritas guru akuntansi masih menggunakan pembelajaran konvensional yaitu penggabungan metode ceramah, tanya jawab dan pemberian tugas serta diskusi sehingga kurang berjalan efektif, sehingga prestasi yang dicapai siswa pun kurang memuaskan. Banyak siswa yang merasa bosan dan jenuh dengan pelajaran akuntansi karena mereka hanya akan mendengarkan penjelasan yang diberikan guru lalu mengerjakan soal-soal latihan, dengan mereka bosan dan jenuh ini prestasi belajar mereka juga akan berkurang dan turun. Sehingga guru harus memilih metode pembelajaran yang menyenangkan dan membuat siswa tertarik dan aktif di dalam kelas.

Dari kondisi di atas, diperlukan suatu model atau metode belajar mengajar yang dapat memberikan penyelesaian terhadap masalah tersebut. Dengan model atau metode pembelajaran ini diharapkan dapat membantu siswa dalam memahami suatu konsep secara utuh dan benar. Untuk itulah diperlukan strategi pembelajaran yang lebih memberdayakan siswa. Sebuah strategi pembelajaran yang tidak mengharuskan siswa menghafal faktafakta, tetapi sebuah strategi yang mendorong siswa untuk aktif dan menemukan sendiri.

Di dalam proses pembelajaran dibutuhkan model-model pembelajaran dan strategi pembelajaran yang lebih menarik siswa untuk lebih tertarik dan aktif di dalam proses pembelajaran. Model-model pembelajaran perlu dikembangkan mengingat adanya perbedaan berbagai macam karakteristik dari siswa. Di dalam kelas kooperatif, para siswa diharapkan dapat saling membantu, saling mendiskusikan dan berargumentasi, untuk mengasah pengetahuan yang mereka kuasai saat itu dan menutup kesenjangan dalam pemahaman masing-masing.

Snowball Throwing/Drilling merupakan metode yang dikembangkan untuk menguatkan pengetahuan yang diperoleh peserta didik dari membaca bahan-bahan bacaan. Dalam metode ini mula-mula guru mempersiapkan paket soal-soal pilihan ganda dan menggelindingkan bola salju berupa soal latihan dengan cara menunjuk atau mengundi untuk mendapatkan seorang peserta didik untuk menjawab soal (Agus Suprijono, 2013: 105-106).

Menurut (Miftahul Huda, 2013: 224) Talking Stick (tongkat berbicara) adalah metode yang digunakan untuk mengajak semua orang berbicara atau menyampaikan suatu 
pendapatnya. Kini metode ini sudah digunakan sebagai metode pembelajaran ruang kelas. Sebagaimana namanya, Talking Stick merupakan metode pembelajaran kelompok dengan bantuan tongkat. Kelompok yang memegang tongkat terlebih dahulu wajib menjawab pertanyaan dari guru setelah mereka mempelajari materi pokoknya. Kegiatan ini diulang terus-menerus sampai semua kelompok mendapat giliran untuk menjawab pertanyaan dari guru.

Model pembelajaraan kooperatif seharusnya juga diterapkan pada siswa kelas XII IPS SMA Negeri 1 Wungu. Karena metode pembelajaran yang digunakan guru akuntansi di kelas hanya pada metode diskusi, tanya jawab, penugasan dan ceramah. Hal tersebut didasarkan pada hasil observasi awal dilapangan ditemukan beberapa permasalahan antara lain siswa yang masih cenderung pasif dalam proses belajar mengajar. Masih banyak siswa yang kurang aktif selama proses pembelajaran berlangsung dan hanya beberapa anak yang aktif. Permasalahan tersebut timbul karena guru kurang variatif dalam menggunakan metode mengajar. Hal tersebut yang kurang memotivasi siswa untuk aktif dalam proses belajar mengajar.

\section{TELAAH PUSTAKA}

\section{Prestasi Belajar}

Kemampuan siswa sangat menentukan keberhasilan siswa dalam memperoleh prestasi. Untuk menentukan berhasil atau tidaknya seorang siswa dalam belajar maka perlu dilakukan suatu evaluasi, tujuannya adalah untuk mengetahui prestasi yang diperoleh siswa setelah proses belajar mengajar berlangsung. Tanpa belajar dan mengikuti evaluasi pembelajaran siswa tidak akan memperoleh prestasi belajar.

Menurut Lanawati (dalam Reni Akbar, 2004: 168) menyatakan bahwa prestasi belajar adalah hasil penilaian pendidik terhadap proses belajar dan hasil belajar siswa sesuai dengan tujuan instruksional yang menyangkut isi pelajaran dan perilaku yang diharapkan dari siswa. Hamdani (2011: 137) menjelaskan bahwa prestasi adalah hasil dari suatu kegiatan yang telah dikerjakan, diciptakan, baik secara individual maupun kelompok. Prestasi tidak akan pernah dihasilkan selama seseorang tidak melakukan kegiatan.

Dari uraian di atas dapat disimpulkan bahwa prestasi belajar akuntansi dapat diartikan sebagai hasil yang dicapai oleh siswa dalam proses belajar akuntansi berupa nilai pengetahuan maupun kecakapan yang diberikan guru dan diukur dengan alat evaluasi berupa tes. Tinggi rendahnya prestasi belajar siswa dapat juga dikarenakan adanya faktor-faktor yang mempunyai pengaruh besar terhadap diri siswa. Sehingga faktor-faktor yang mempengaruhi prestasi belajar siswa tersebut sebaiknya harus diperhatikan agar mencapai prestasi belajar yang diinginkan.

Hamdani (2011: 139-143) faktor-faktor yang mempengaruhi prestasi belajar dapat digolongkan menjadi dua bagian, yaitu:

1) Faktor internal, yakni faktor yang berasal dari siswa. Faktor ini antara lain sebagai berikut: (a) Kecerdasan (inteligensi), (b) Faktor jasmaniah atau faktor fisiologis, (c) Sikap, (d) Minat, (e) Bakat, (f) Motivasi.

2) Faktor eksternal, yakni faktor yang berasal dari luar siswa. Faktor eksternal terdiri atas dua macam, yaitu lingkungan sosial dan lingkungan nonsosial. Lingkungan sosial meliputi guru, kepala sekolah, staf administrasi, teman-teman sekelas, rumah tempat tinggal siswa, alat-alat belajar, dan lain-lain. Dan lingkungan nonsosial meliputi gedung sekolah, tempat tinggal, dan waktu belajar. 
ASSETS : Jurnal Akuntansi dan Pendidikan, Vol.4 No.1, April 2015

168-169) berpendapat bahwa prestasi belajar ditentukan oleh faktor- faktor seperti:

1) Faktor- faktor yang ada pada siswa: (a) Taraf inteligensi, (b) Bakat khusus, (c) Taraf pengetahuan yang dimiliki, (d) Taraf kemampuan berbahasa, (e) Taraf organisasi kognitif, (f) Motivasi, (g) Kepribadian, (h) Perasaan, (i) Sikap, (j) Minat,

2) Kondisi fisik dan psikis (termasuk cacat fisik dan kelainan psikologis).

3) Faktor-faktor yang ada pada lingkungan sekolah: (a) Hubungan antar-orang tua, (b) Hubungan orang tua-anak,(c) Jenis pola asuh, (d)Keadaan sosial ekonomi keluarga.

4) Faktor-faktor yang di lingkungan sekolah: (a) Guru: kepribadian guru, sikap guru terhadap siswa, keterampilan didaktik dan gaya mengajar; (b) Kurikulum, (c) Organisasi sekolah, (d) Sistem sosial di sekolah, (e) Keadaan fisik sekolah dan fasilitas pendidikan, (f) Hukum sekolah dengan orang tua, (g) Lokasi sekolah.

5) Faktor-faktor pada lingkungan sosial yang lebih luas

a) Keadaan sosial, politik, dan ekonomi.

b) Keadaan fisik: cuaca, iklim.

\section{Model Pembelajaran Kooperatif}

a. Pengertian Model Pembelajaran

Pembelajaran sangat penting untuk diketahui oleh para calon guru agar proses mengajar yang dilakukan dapat berjalan dengan baik. Dalam suatu pembelajaran terdapat berbagai macam model-model pembelajaran yang dapat dipilih oleh guru dalam suatu proses belajar mengajar di kelas. Agar membuat siswa lebih senang dan tidak bosan saat belajar, dengan harapan siswa menjadi lebih aktif pada saat proses belajar mengajar. Hal ini didukung pendapat Agus Suprijono (2013: 45-46) berpendapat bahwa model pembelajaran merupakan landasan praktik pembelajaran atau pola yang digunakan untuk penyusunan kurikulum, mengatur materi, dan memberi petunjuk kepada guru kelas. Model pembelajaran dapat disimpulkan merupakan suatu rencana yang digunakan untuk proses pembelajaran, untuk merancang pembelajaran di kelas. Dengan adanya model-model pembelajaran diharapkan proses belajar mengajar akan berjalan lebih aktif.

b. Pengertian Model Pembelajaran Kooperatif

Pembelajaran kooperatif (cooperative learning) berasal dari kata cooperative yang artinya saling mengerjakan sesuatu secara bersama dalam satu kelompok atau satu tim. Pembelajaran ini memfokuskan pada pembelajaran yang dilakukan secara berkelompok. Sehingga diharapkan siswa akan lebih aktif di dalam kelas.

Hal ini didukung oleh pendapat para ahli diantaranya Slavin (dalam Isjoni, 2013: 15) mengemukakan, "cooperative learning" adalah suatu model pembelajaran dimana siswa belajar dan bekerja dalam kelompok-kelompok kecil secara kolaboratif yang anggotanya terdiri dari 4 sampai 6 orang, dengan struktur kelompoknya heterogen. Menurut Slavin (2013: 4) model pembelajaran kooperatif (cooperative learning) adalah pembelajaran yang merujuk pada berbagai macam metode pengajaran, dimana siswa bekerja dalam kelompok-kelompok kecil untuk saling membantu satu sama lainnya. Dengan ini siswa diharapkan dapat saling membantu, saling mendiskusikan dan berargumentasi, untuk mengasah pengetahuan yang mereka kuasai saat itu dan menutup kesenjangan dalam pemahaman masing-masing.

Sedangkan menurut Sunal dan Hans (dalam Isjoni, 2013: 15) mengemukakan pembelajaran koopratif merupakan suatu cara pendekatan atau serangkaian strategi yang khusus dirancang untuk memberi dorongan kepada peserta didik agar bekerja 
sama selama proses pembelajaran. Berdasarkan pendapat diatas, maka dapat disimpulkan bahwa pembelajaran cooperative learning dapat mengajarkan kepada siswa untuk saling berkerjasama serta dapat menerima pendapat dari teman, disamping itu untuk melatih siswa untuk berani mengemukakan pendapatnya. Dalam penelitian ini pendapat ahli yang digunakan menurut Sunal dan Hans, pembelajaran koopratif merupakan suatu cara pendekatan atau serangkaian strategi yang khusus dirancang untuk memberi dorongan kepada peserta didik agar bekerja sama selama proses pembelajaran.

c. Model Pembelajaran Kooperatif Tipe Snowball Throwing

Snowball throwing adalah model pembelajaran yang didasari pendekatan konseptual dan mengakomodasikan beberapa pendekatan dalam pembelajaran bahasa, di antaranya pendekatan komunikatif dan keterampilan proses. Snowball throwing menurut asal katanya berarti "bola salju bergilir" dapat diartikan sebagai model pembelajaran dengan menggunakan bola pertanyaan dari kertas yang digulung bulat berbentuk bola kemudian dilemparkan secara bergiliran di antara anggota kelompok. Ada peningkatan keaktifan belajar siswa dari segi kerjasama, bertanya dan menjawab pertanyaan dengan model pembelajaran snowball throwing baik dengan teknik tanya jawab berpasangan maupun dengan diskusi kelompok. Dalam konteks pembelajaran, snowball throwing ditetapkan dengan melempar segumpalan kertas yang menunjuk siswa yang diharuskan menjawab soal dari guru. Strategi ini digunakan untuk memberikan konsep pemahaman materi yang sulit kepada siswa serta dapat juga digunakan untuk mengetahui sejumlah mana pengetahuan dan kemampuan siswa dalam materi tersebut.

Strategi pembelajaran ini melatih siswa untuk lebih tanggap menerima pesan dari orang lain dan menyampaikan pesan tersebut kepada teman satu kelompoknya. Lemparan pertanyaan tidak menggunakan tongkat sebagaimana pada strategi talking stick, tetapi menggunakan kertas berisi pertanyaan yang diremas menjadi sebuah bola kertas lalu dilempar-lemparkan kepada siswa lain. Siswa yang mendapat bola kertas lalu membuka dan menjawab pertanyaan di dalamnya. Beberapa ahli menyatakan bahwa model ini tidak hanya unggul dalam membantu siswa memahami konsep yang sulit, tetapi juga sangat berguna untuk menumbuhkan kemampuan berpikir kritis, bekerja sama, dan membantu teman. Dalam pembelajaran kooperatif, siswa terlibat aktif pada proses pembelajaran sehingga memberikan dampak positif terhadap kualitas interaksi dan komunikasi yang berkualitas, dapat memotifasi siswa untuk meningkatkan prestasi belajarnya (Isjoni, 2013: 16).

d. Model Pembelajaran Kooperatif Tipe Talking Stick

Model pembelajaran Talking Stick adalah model pembelajaran dengan menggunakan tongkat. Penerapan model ini ditujukan untuk meningkatkan aktivitas siswa dalam pembelajaran. Penerapan pembelajaran dengan model talking stick murni berorientasi pada aktivitas individu siswa yang dilakukan dalam bentuk permainan. Untuk meningkatkan aktivitas belajar siswa dalam model pembelajaran talking stick tidak serta merta dapat dilakukan jika siswa belum memiliki stock of knowledge atau prior knowledge (pengetahuan siswa terhadap materi yang akan dipelajari) dari hal yang sedang dipelajarinya, dan pemberian pengalaman belajar sebagai previous experience (pengetahuan sebelumnya) sangat dibutuhkan (Agus Suprijono, 2013: 16).

Talking stick merupakan model pembelajaran yang mendorong peserta didik untuk berani mengemukakan pendapat. Metode ini dapat digunakan dalam pembelajaran inovatif yang berpusat pada siswa. Talking stick merupakan metode pembelajaran dengan bantuan tongkat, siapa yang memegang tongkat wajib menjawab 
pertanyaan dari guru setelah siswa mempelajari materi pokoknya. Manfaat pembelajaran ini yakni menguji kesiapan siswa, melatih keterampilan dalam membaca dan memahami materi pelajaran dengan cepat, dan mengajak mereka untuk terus siap dalam situasi apa pun (Miftahul Huda, 2013: 225). Model pembelajaran ini akan berjalan baik dikelas yang kemampuannya merata, namun sebenarnya kelas dengan kemampuan siswa yang bervariasi juga membutuhkan model pembelajaran ini. Karena dengan kemampuan siswa yang beragam, maka siswa yang kurang akan sangat terbantu dan termotivasi siswa yang memiliki kemampuan lebih.

\section{HIPOTESIS PENELITIAN}

H1: Terdapat perbedaan prestasi belajar akuntansi siswa kelas XII IPS SMA Negeri 1 Wungu antara yang menggunakan metode pembelajaran kooperatif tipe Snowball Throwing dengan Talking Stick.

H2: Prestasi belajar akuntansi siswa kelas XII IPS SMA Negeri 1 Wungu dengan menggunakan metode pembelajaran kooperatif tipe Snowball Throwing lebih sesuai daripada metode pembelajaran kooperatif tipe Talking Stick.

\section{METODE PENELITIAN}

Populasi yang diambil dalam penelitian ini adalah siswa kelas XII IPS SMA Negeri 1 Wungu yang semuanya berjumlah 32 siswa. Sampel yang digunakan dalam penelitian ini adalah kelas XII IPS 1 dengan menggunakan metode Snowball Throwing sejumlah 16 siswa dan kelas XII IPS 2 dengan menggunakan metode Talking Stick sejumlah 16 siswa. Total sampel pada penelitian ini adalah 32 siswa. Dalam penelitian ini teknik pengambilan sampel dilakukan dengan Sampling Jenuh, yaitu semua siswa kelas XII IPS di SMA Negeri 1 Wungu yang berjumlah 32 siswa diharapkan benar-benar dapat mewakili sifat populasi yang ada.

\section{HASIL PENELITIAN}

\section{Hasil Uji Instrumen}

Uji instrumen dilakukan pada kelas XII IPS SMA Negeri 1 Wungu dengan jumlah 32 siswa. Instrumen yang digunakan berupa tes prestasi yang diberikan kepada siswa sejumlah 25 butir soal. Uji instrumen tes prestasi meliputi validitas dan reliabilitas. Adapun hasil uji instrumen prestasi dapat dilihat dalam tabel berikut:

\section{Tabel 1}

Hasil Analisis Instrumen Soal Tes Uji Coba

\begin{tabular}{lllll}
\hline No & $\mathrm{r}_{\text {hitung }}$ & $\mathrm{r}_{\text {tabel }}$ & Keterangan & Reliabelitas \\
\hline 1 & 0,48 & 0,35 & Valid & Desimpulan \\
2 & 0,49 & 0,35 & Valid & Digunakan \\
3 & 0,54 & 0,35 & Valid & Digunakan \\
4 & 0,63 & 0,35 & Valid & Digunakan \\
5 & 0,57 & 0,35 & Valid & Digunakan \\
6 & 0,46 & 0,35 & Valid & Digunakan \\
7 & 0,38 & 0,35 & Valid & Digunakan \\
8 & 0,55 & 0,35 & Valid & Digunakan \\
9 & 0,22 & 0,35 & Tidak Valid & Tidak Digunakan \\
10 & 0,37 & 0,35 & Valid & Digunakan \\
11 & 0,28 & 0,35 & Tidak Valid & Tidak Digunakan \\
12 & 0,39 & 0,35 & Valid & Digunakan \\
13 & 0,41 & 0,35 & Valid & Digunakan \\
14 & 0,35 & 0,35 & Valid & Digunakan \\
15 & 0,45 & 0,35 & Valid & Digunakan \\
16 & 0,41 & 0,35 & Valid & Digunakan \\
17 & $-0,10$ & 0,35 & Tidak Valid & Tidak Digunakan \\
18 & 0,24 & 0,35 & Valid Valid & Tidak Digunakan \\
19 & 0,37 & 0,35 & Valid & Digunakan \\
20 & 0,35 & 0,35 & & Digunakan \\
\hline
\end{tabular}


Menurut Nitko suatu instrumen dikatakan valid apabila koefisien korelasinya lebih dari 0,30. Untuk uji validitas instrumen tes prestasi belajar (tes formatif), dalam penelitian ini penulis menggunakan rumus Karl Pearson. Hasil uji coba instrumen formatif akuntansi sebanyak 20 butir soal terhadap 32 responden kelas XII di SMA Negeri 1 Wungu, maka dapat diketahui bahwa ternyata 4 soal dinyatakan tidak valid karena korelasinya $\leq 0,3$ yaitu nomor $9,11,17$ dan 18 .

Dalam penelitian ini,uji reliabilitas menggunakan rumus KR-20. Butir soal dikatakan reliabeli jika $r_{11}>r_{\text {tabel }}$. Dalam penelitian ini nilai dari $r_{t a b e l}=0,349$ dan $\mathrm{n}=32$, sehingga $r_{x y} \leq 0,349$. Hasil uji coba instrumen tes formatif terhadap 32 responden diperoleh $r_{11}>0,69$.

2. Hasil Uji Normalitas

Uji normalitas digunakan untuk mengetahui apakah variabel dependen, independen atau keduanya berdistribusi normal, mendekati normal atau tidak normal. Hasil analisis uji normalitas menggunakan uji Liliefors.

Tabel 2

Rangkuman Hasil Analisis Uji Normalitas

\begin{tabular}{ccclcl}
\hline Kelas & $L_{\text {obs }}$ & DK & $L_{\text {tabel }} / D K$ & Keputusan & Kesimpulan \\
\hline Kelas XII IPS 1 & & & & $\mathrm{H}_{0}$ & Berdistribusi \\
(Snowball & 0,1682 & 0,213 & $D K=\{L / L>$ & Ditolak & Normal \\
Throwing) & & & $0213\}$ & $\mathrm{H}_{0}$ & Berdistribusi \\
$\begin{array}{c}\text { Kelas XII IPS 2 } \\
\text { (Talking Stick) }\end{array}$ & 0,1700 & 0,213 & & Ditolak & Normal \\
\hline
\end{tabular}

3. Hasil Uji Statistik Deskriptip

Perbandingkan prestasi belajar akuntansi siswa kelas XII IPS SMA Negeri 1 Wungu dengan menggunakan metode pembelajaran kooperatif tipe Snowball Throwing memberikan prestasi lebih tinggi daripada metode Talking Stick, maka dapat disimpulkan metode Snowball Throwing lebih sesuai dari pada metode Talking Stick. Hal ini dapat dilihat perbedaan pada tabel dibawah ini.

Tabel 3

Uji Perbandingan

\begin{tabular}{lccccc}
\hline Kelas & & $Z_{\text {hitung }}$ & $Z_{\text {tabel }}$ & $Z_{\text {hitung }} / Z_{\text {tabel }}$ & Keputusan \\
\hline $\begin{array}{l}\text { Kelas XII IPS } \\
\begin{array}{l}\text { Snowball Throwing) } \\
\text { Kelas XII IPS }\end{array}\end{array}$ & 4,54 & 1,645 & $\begin{array}{c}Z_{\text {tabel }}<Z_{\text {hitung }} \\
1,645<4,54\end{array}$ & $\mathrm{H}_{0}$ Diterima \\
$\begin{array}{l}\text { Kelas } \\
\text { (Talking Stick) }\end{array}$ & 0,04 & 1,645 & $\begin{array}{c}Z_{\text {tabel }}>Z_{\text {hitung }} \\
1,645>0,04\end{array}$ & $\mathrm{H}_{0}$ Ditolak \\
\hline
\end{tabular}

\section{PEMBAHASAN}

Berdasarkan hasil uji hipotesis data disimpulkan bahwa metode pembelajaran kooperatif tipe Snowball Throwing memberikan prestasi lebih tinggi daripada metode Talking Stick, maka dapat disimpulkan metode Snowball Throwing lebih sesuai dari pada metode Talking Stick. Perbedaan menggunakan uji statistik deskriptif sebagai alat perhitungan.

Rata-rata prestasi belajar yang diperoleh, siswa kelas XII IPS 1 yang diajar dengan menggunakan metode pembelajaran snowball throwing memiliki rata-rata prestasi belajar 
sebesar 84,63 yang lebih tinggi daripada rata-rata prestasi belajar siswa kelas XII IPS 2 yaitu 75,13 yang diajar dengan menggunakan metode pembelajaran talking stick. Siswa di SMA Negeri 1 Wungu cenderung lebih semangat belajar bila menggunakan metode snowball throwing karena siswa SMA Negeri 1 Wungu menyukai pembelajaran yang menyenangkan, mengasikkan, tidak membosankan, berani mengemukakan pendapatnya dan saling menghargai pendapat dari siswa yang lainnya.

Cara mengatasi untuk metode pembelajaran ini sebaiknya pembahasan materi dikembangkan lebih luas lagi, yakni dengan cara memberikan contoh-contoh pada kehidupan sehari-hari siswa agar lebih mudah untuk dimengerti. Kemudian untuk menciptakan suasana kelas yang kondusif maka diperlukan kontrol yang baik dari guru. Guru harus pandai-pandai membuat suasana serius tapi santai agar siswa tidak tegang. Dan menggunakan metode pembelajaran berganti-ganti agar siswa tidak bosan. Di dalam proses pembelajaran dibutuhkan model-model pembelajaran dan strategi pembelajaran yang lebih menarik siswa untuk lebih tertarik dan aktif di dalam proses pembelajaran. Model-model pembelajaran dikembangkan utamanya beranjak dari adanya perbedaan berkaitan dengan berbagai karateristik siswa (Aunurrahman, 2009: 141).

Penerapan metode pembelajaran kooperatif tipe snowball throwing dalam pembelajaran akuntansi ternyata terdapat perbedaan dengan metode pembelajaran kooperatif tipe talking stick. Pada penerapan metode pembelajaran kooperatif tipe snowball throwing siswa lebih termotivasi untuk bersaing dan berani menggemukakan pendapatanya, karena soal berasal dari pertanyaan yang dibuat oleh temannya sendiri. Pembelajaran snowball throwing dapat meningkatkan prestasi belajar karena proses pembelajaran yang dilakukan sangat menyenangkan. Sedangkan dalam penerapan metode pembelajaran kooperatif tipe talking stick siswa menjadi tegang dan was-was ketika tongkat diputar, sehingga mereka bertanya-tanya apakah bisa menjawab pertanyaan dari guru atau tidak.

Temuan dari penelitian tentang perbedaan prestasi belajar dengan menggunakan metode pembelajaran kooperatif tipe Snowball Throwing dan Talking Stick pada siswa kelas XII IPS di SMA Negeri 1 Wungu ini memiliki hasil temuan penelitian: Bahwa prestasi belajar akuntansi dengan menggunakan metode pembelajaran kooperatif untuk kelas XII IPS di SMA Negeri 1 Wungu lebih tepat menggunakan metode Snowball Throwing dari pada Talking Stick, karena ada peningkatan keaktifan belajar siswa dari segi kerjasama, bertanya dan menjawab pertanyaan dengan model pembelajaran baik dengan teknik tanya jawab berpasangan maupun dengan diskusi kelompok. Selain itu metode ini tidak hanya unggul dalam membantu siswa memahami konsep yang sulit, tetapi juga sangat berguna untuk menumbuhkan kemampuan berpikir kritis, bekerja sama, dan membantu teman.

\section{SIMPULAN}

Berdasarkan hasil analisis dan pembahasan penelitian tentang perbedaan prestasi belajar akuntansi dengan menggunakan metode pembelajaran kooperatif tipe Snowball Throwing dan Talking Stick pada siswa kelas XII IPS di SMA Negeri 1 Wungu, maka dapat ditarik kesimpulan sebagai berikut:

1. Ada perbedaan prestasi belajar akuntansi siswa kelas XII IPS SMA Negeri 1 Wungu dengan menggunakan metode pembelajaran kooperatif tipe Snowball Throwing dengan menggunakan metode pembelajaran kooperatif tipe Talking Stick. 
2. Penggunaan metode pembelajaran kooperatif tipe Snowball Throwing lebih sesuai dari pada metode pembelajaran kooperatif tipe Talking Stick dalam peningkatan prestasi belajar akuntansi siswa kelas XII IPS SMA Negeri 1 Wungu.

Peneliti menyarakna perlu adanya penelitian lanjutan dari penelitian ini pada mata pelajaran dan materi yang lain serta pada siswa SD, SMP atau SMA yang lain dengan populasi yang lebih besar, apakah didapatkan kesimpulan yang sama atau tidak.

\section{DAFTAR PUSTAKA}

Agus Suprijono. 2013. Cooperative Learning Teori dan Aplikasi Paikem. Yogyakarta: Pustaka Pelajar.

Aunurrahman. 2012. Belajar dan Pembelajaran. Bandung: Alfabeta.

Budiyono. 2013. Statistika untuk Penelitian. Surakarta: Universitas Sebelas Maret Press.

Dimyati, Mudjiono. 2009. Belajar dan Pembelajaran. Jakarta: Rineka Cipta.

Hamid Darmadi. 2012. Kemampuan Dasar Mengajar Landasan Konsep dan Implementasi. Bandung: Alfabeta.

Hamdani. 2011. Strategi Belajar Mengajar. Bandung: Pustaka Setia.

Isjoni. 2013. Pembelajaran Kooperatif:Meningkatkan Kecerdasan Komunikasi Antar Peserta Didik. Yogyakarta: Pustaka Pelajar.

Miftahul Huda. 2013. Model-Model Pengajaran dan Pembelajaran. Yogyakarta: Pustaka Pelajar.

Reni Akbar Hawadi. 2004. Akselerasi. Jakarta: PT Gramedia Widiasarana Indonesia.

Slavin R E. 2013. Cooperative Learning Teori, Riset dan Praktik. Bandung: Nusa Media.

Slameto. 2013. Belajar dan Faktor-Faktor yang Mempengaruhi. Jakarta: Rineka Cipta.

Soemarso. 2004. Akuntansi Suatu Pengantar. Jakarta: Salemba Empat.

Sugiyono. 2010. Metode Penelitian Pendidikan Pendekatan Kuantitatif, Kualitatif, dan $R \& D$. Bandung: Alfabeta. . 2013. Cara Mudah Menyusun Skripsi, Tesis, dan Disertasi. Bandung: Alfabeta.

Suharsimi Arikunto. 2010. Prosedur Penelitian Suatu Pendekatan Praktik. Jakarta: Rineka Cipta.

. 2013. Dasar-Dasar Evaluasi Pendidikan. Jakarta: Bumi Aksara.

Yatim Riyanto. 2009. Paradigma Baru Pembelajaran:Sebagai Referensi Bagi Guru Pendidik dalam Implementasi Pembelajaran yang Efektif dan Berkualitas. Jakarta: Kencana.

Zainal Aqib. 2013. Model Media dan Strategi Pembelajaran Kontekstual. Bandung: Yrama Widya.

Zainal Arifin. 2014. Evaluasi Pembelajaran. Bandung: PT Remaja Rosdakarya. 